\title{
Photoperiodic regulation of reproduction in the male silver fox (Vulpes vulpes)
}

\author{
M. Forsberg, J. A. Fougner*, P. O. Hofmo†, Malgorzata Madej and \\ E. J. Einarsson*
}

Department of Clinical Chemistry and Obstetrics and Gynaecology, College of Veterinary Medicine, Swedish University of Agricultural Sciences, P.O. Box 7038, S-750 07 Uppsala, Sweden;

*Norwegian Fur Breeders Association, Ökern torgvei 13, 0580 Oslo 5, Norway; and $\dagger$ Department of Reproductive Physiology \& Pathology, Norwegian College of Veterinary Medicine, P.O. Box 8146, Dep., 0033 Oslo 1, Norway

Summary. Six silver fox males were exposed to short days (6L:18D) from February, when the testes were fully developed, until June 1986 (Group 6L). Eight males maintained in natural daylight served as controls (Group N). Histological sections from the testes of 2 males in Group 6L killed in June indicated full spermatogenic activity. Three blue fox vixens inseminated the following year with semen collected and frozen in June from 3 males in Group $6 \mathrm{~L}$ failed to produce litters. One possible explanation for the reproductive failures could have been that the high environmental temperatures in June influenced semen quality. There was no significant difference $(P>0.05)$ in LH release in response to GnRH stimulation in June, but testosterone response to LH release was significantly higher $(P<0.01)$ in animals subjected to a restricted photoperiod, demonstrating that testicular testosterone production was maintained longer than in control animals. Two males in Group 6L were retained in 6L:18D from June until December 1986 and then exposed to natural daylight until the end of the study in May 1987 (Group 6L:6L:N). These males started to shed their winter coat and showed clinical signs of testicular regression in December, i.e. after $\sim 11$ months exposure to $6 \mathrm{~L}: 18 \mathrm{D}$. The 2 remaining males in Group $6 \mathrm{~L}$ were moved to cages with natural daylight in June 1986, where they were kept until the end of the experiment (Group 6L: $\mathrm{N}: \mathrm{N}$ ). These males displayed testicular regression soon after the change in photoperiod but maintained their capacity for testicular redevelopment during the following breeding season.

Five males from Group $\mathrm{N}$ were moved from natural daylight to 6L:18D in June 1986, when the testes were fully regressed. The animals were kept in 6L:18D until December 1986 and then exposed to natural daylight until the end of the study (Group $\mathrm{N}: 6 \mathrm{~L}: \mathrm{N}$ ). The 3 remaining males in Group $\mathrm{N}$ continued to serve as controls (Group $\mathrm{N}$ : $\mathrm{N}: \mathrm{N}$ ). Six blue fox vixens inseminated in the natural breeding season with semen collected and frozen in December 1986 from 4 males in Group N:6L:N conceived with an average litter size of $8.8 \pm 1 \cdot 7$. Plasma concentrations of $\mathrm{LH}$ in response to $\mathrm{GnRH}$ stimulation in October and November 1986 indicated no variation of the pituitary to respond by LH release. In contrast, total testosterone release was twice as high in animals subjected to a restricted photoperiod compared with control animals, indicating that short days had a stimulatory effect on testicular redevelopment.

The results demonstrate that artificial illumination can be used to increase the reproductive capacity of silver fox males.

Keywords: light; reproduction; silver fox; male; semen; testes 


\section{Introduction}

The reproductive physiology of many domesticated and semi-domesticated animals varies with season. In the wild these seasonal traits have a survival value whereas in captivity they can pose a management problem and constrain productivity. Silver fox (Vulpes vulpes) males show a seasonal reproductive pattern, with testicular activity varying considerably throughout the year. In the northern hemisphere male silver foxes attain peak reproductive capacity for approximately 6-8 weeks during February and March. Daylength is considered to be the principal environmental cue dictating the timing of the reproductive changes. In the arctic fox (Alopex lagopus), reproductive physiology can be influenced by regulating the photoperiod by artificial lighting (Kuznetsov, 1979). The aim of the present study was to determine whether the breeding season of the male silver fox could be hastened or prolonged via restricted photoperiod.

\section{Materials and Methods}

Animals and experimental design. Fourteen adult silver fox males, aged 1-3 years when entering the study, were housed individually at the Research Farm for Furbearing Animals, University of Agricultural Sciences, Uppsala, Sweden (latitude: $59^{\circ} 50^{\prime} \mathrm{N}$; longitude; $17^{\circ} 50^{\prime} \mathrm{E}$ ) from January 1986 until the end of May 1987. The animals were within visual and olfactory contact of vixens on the farm, but none of the males was allowed sexual contact during the study period. The animals were given water ad libitum and fed the standard ration wet feed of the farm, consisting of rumen, cattle liver, muscular meat of cattle, cod offal, filleting scrap of Baltic herring, cattle skulls, cereals (wheat, barley, oats) and a vitamin mixture.

The experimental design is depicted in Fig. 1. On 6 February 1986, when all the males had fully developed testes, 6 of the 14 males were placed in a light-proof building and provided with artificial light from three, white fluorescent strip lights providing illumination of 250-300 lux at eye level. The animals were exposed to $6 \mathrm{~h}$ of light from 08:00 to $14: 00 \mathrm{~h}$ and $18 \mathrm{~h}$ of darkness (Group $6 \mathrm{~L}$ ). Light treatment was started abruptly without any transition from the natural photoperiod. Eight males served as controls and were maintained under natural photoperiodic conditions (Group N).

On 20 June 1986, 5 males from Group $\mathrm{N}$ were transferred to $6 \mathrm{~L}: 18 \mathrm{D}$, where they were kept until 20 December 1986. Thereafter they were exposed to natural daylight until the end of the study in May 1987 (Group N:6L:N). Two males from Group $6 \mathrm{~L}$ also received this sequence of photoperiodic treatment beginning 20 June (Group 6L:6L:N), and another 2 animals from Group $6 \mathrm{~L}$ were moved to natural daylight where they remained until the end of the study (Group 6L:N:N). The 3 remaining animals from the original control group continued to serve as controls (Group N: $\mathrm{N}: \mathrm{N})$.

Before the experiment started in February 1986 semen was collected from all 14 males to verify normal testicular activity. On different occasions during the study, attempts were made to collect semen for evaluation of testicular function. Semen for freezing was collected in June and December 1986 (Fig. 1). Ten blue fox vixens from one farm, aged 1-3 years, were inseminated on 1-3 April 1987 to test the fertilizing ability of the frozen semen.

Blood sampling. To monitor pituitary LH release and subsequent testicular testosterone response to GnRH injection, blood samples were collected at the times indicated in Fig. 1. To allow frequent blood sampling the animals were premedicated with $2 \mathrm{mg}$ acepromazine/ $\mathrm{kg}$ (Plegicil: Agrivet AB, Uppsala, Sweden; $10 \mathrm{mg} / \mathrm{ml}$ ) given subcutaneously 5$10 \mathrm{~min}$ before induction of anaesthesia. Ketamine (Ketalar: Parke-Davis, Raritan, NJ, USA; $50 \mathrm{mg} / \mathrm{ml}$ ) was used as anaesthetic in an intramuscular dose of $10 \mathrm{mg} / \mathrm{kg}$.

On each blood collection occasion, sampling was performed 4 times at 20-30-min intervals between 11:00 and 15:00 h. An intramuscular injection of $20 \mu \mathrm{g}$ gonadotrophin-releasing hormone (Nialutin: Novo Industry A/S, Bagsvaerd, Denmark; $20 \mu \mathrm{g} / \mathrm{ml}$ ) was given immediately after taking the second blood sample. All blood samples were collected in heparinized tubes. Plasma was immediately centrifuged and stored at $-20^{\circ} \mathrm{C}$ until assayed.

Hormone assays. Plasma concentrations of testosterone were determined by radioimmunoassay (Oltner et al., 1979). Serial dilutions of silver fox plasma containing a high testosterone concentration produced a doseresponse curve parallel to the standard curve. The inter-assay coefficients of variation for quality control samples were $5 \cdot 3 \%($ mean $=9 \cdot 3 \mathrm{nmol} / 1, n=5), 4 \cdot 3 \%($ mean $=19.9 \mathrm{nmol} / 1, n=5)$ and $5 \cdot 2 \%($ mean $=26 \cdot 3 \mathrm{nmol} / 1, n=3)$, respectively.

Plasma concentrations of LH were determined by a heterologous radioimmunoassay (Mondain-Monval et al., 1984) with certain modifications. The iodination (carrier-free ${ }^{125} \mathrm{I}$, Amersham International plc, Bucks, UK) of ovine LH (oLH, LER-1056 C2) was performed by the chloramine-T method (Greenwood et al., 1963), as modified by Stupnicki \& Madej (1976), except that $8 \mu \mathrm{g}$ chloramine-T per $2 \mu \mathrm{g}$ glycoprotein and an exposure time of $40 \mathrm{sec}$ were used. The iodinated material was immediately separated from unreacted ${ }^{125} \mathrm{I}$ by chromatography on a Sephadex G25M column $(1.5 \times 5.6 \mathrm{~cm})$. The radioiodinated hormone was stored at $4^{\circ} \mathrm{C}$. Before use ${ }^{125} \mathrm{I}$-labelled oLH was first adsorbed by cellulose (Whatman CF11) and then eluted with $10 \mathrm{~mm}$-sodium phosphate buffer, $\mathrm{pH} 7 \cdot 5$, containing $6 \%$ 

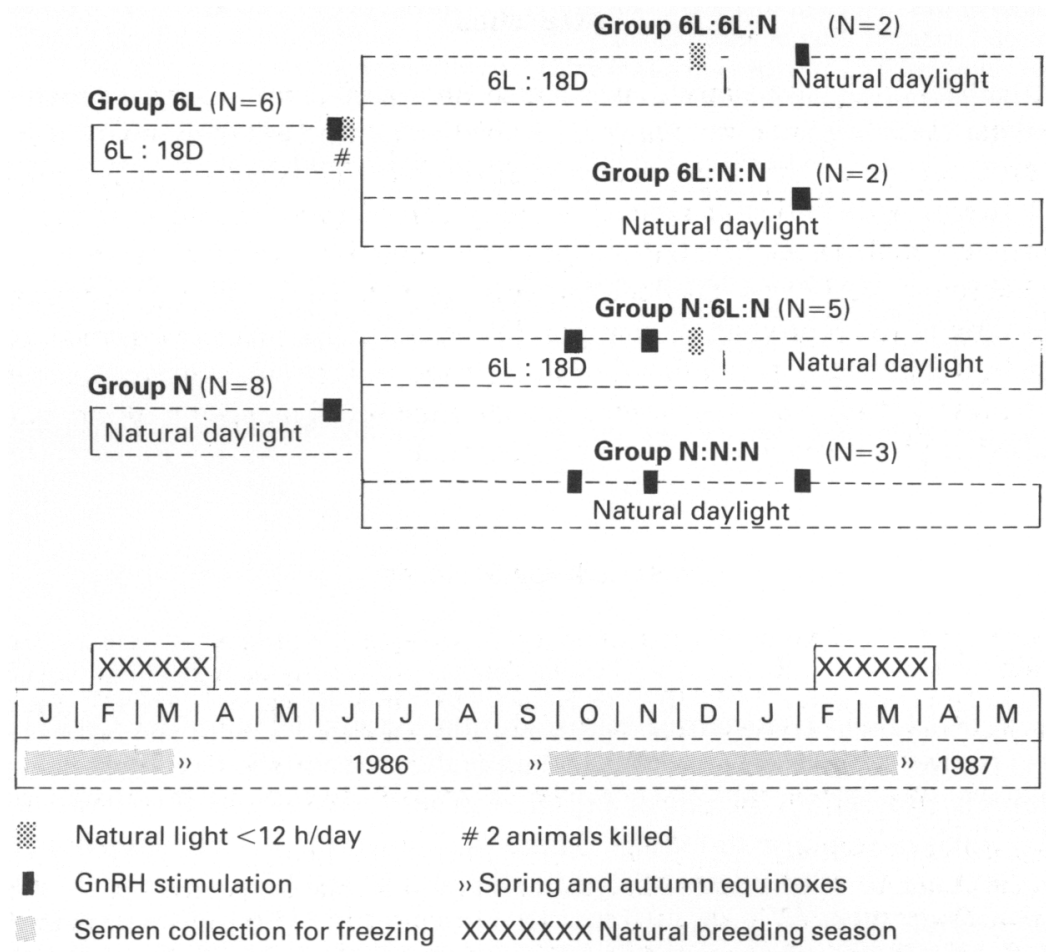

Fig. 1. The experimental design. In June 1986, 3 animals from Group $N$ and 3 animals from Group $6 \mathrm{~L}$ were subjected to GnRH challenge while on all subsequent occasions 2 animals per group were challenged. Semen for freezing was collected in June 1986 from 3 males in Group 6L and in December 1986 from 1 male in Group 6L:6L:N and 4 males in Group N:6L:N.

BSA. Radioactivity was quantified in a gamma counter (Searle Analytic Inc., IL, USA). The antiserum against ovine LH (GDN No. 15) was used at a final dilution of 1:150 000. Dog LH (LER-1685-1) was used as standard. Overnight incubation, including a 2-h delay in the addition of the tracer, was carried out at room temperature. The separation of free from antibody-bound hormone was achieved by adding $0.5 \mathrm{ml}$ of a second antibody coupled to Micro Sepharose beads (Pharmacia AB, Uppsala, Sweden) and, after incubation at room temperature for $30 \mathrm{~min}$, the contents of the tubes were centrifuged for $20 \mathrm{~min}$ at $1500 \mathrm{~g}$.

The oLH antiserum bound $35.8 \%$ (s.d. $=2 \cdot 1, n=5$ ) of the ${ }^{125}$ I-labelled $\mathrm{oLH}$, and the standard curve ranged from 0.1 to $3.2 \mathrm{ng}$. Dilutions of silver fox plasma from $100 \mu \mathrm{l}$ to $25 \mu \mathrm{l}$ were parallel to the dog LH standard. The sensitivity of the assay, calculated from the precision profile, was $0.06 \mathrm{ng} /$ tube (s.d. $=0.02, n=5$ ), corresponding to $0.6 \mu \mathrm{g} / \mathrm{l}$ for $100 \mu \mathrm{l}$ samples. The amount of $\mathrm{dog} \mathrm{LH}$ needed to cause $50 \%$ inhibition was $0.79 \mathrm{ng} / \mathrm{tube}(\mathrm{s} . \mathrm{d} .=0.09$ ). The intra-assay coefficient of variation for $\mathrm{LH}$ concentrations in the range of 2.6 to $64.0 \mu \mathrm{g} / \mathrm{l}$ was below $10 \%$. The coefficient of variations for three pooled plasma samples of silver fox origin, estimated in 3-5 different assays, were $211.4 \%($ mean $=1.4 \mu \mathrm{g} / 1), 7.7 \%($ mean $=41.4 \mu \mathrm{g} / \mathrm{l})$ and $9.0 \%($ mean $=59.2 \mu \mathrm{g} / \mathrm{l})$. The slope of the dose-response curve in 5 assays was -1.158 (s.d. $=0.080)$ after logit-log transformation. When known amounts of dog LH were added to silver fox plasma the recovery of LH averaged $101.0 \%(\mathrm{s.d}=11.4, n=10)$.

All hormone concentrations given represent the mean of duplicate determinations.

The amounts of testosterone and LH released during the first $60 \mathrm{~min}$ after $\mathrm{GnRH}$ injection were assessed by calculating the areas under the release curves for the respective hormones according to the formula;

Hormone $(\mathrm{H})$ response $=\Sigma\left(\left(\mathrm{H}_{\mathrm{i}}+\mathrm{H}_{\mathrm{i}}+20\right) / 2\right) \times 20 \mathrm{~min}$;

where $\mathrm{i}=0,20$ or $40 \mathrm{~min}$.

Analysis of spermatogenic activity. Two males in Group 6L were killed on 20 June 1986 and their testes were removed for histological examination of spermatogenic activity (Smith et al., 1987).

Semen collection and treatment. Semen was collected by digital manipulation and fractionated as described by Aamdal (1972). The sperm-rich fraction was initially diluted 1:3 in Varohm (Kiew) extender (Haeger \& Mäckle, 1971). Semen quality was estimated by light microscopy within $10 \mathrm{~min}$ after collection. 
Semen for freezing was diluted in Tris-fructose-citric acid extender, pH 6.8 (Andersen, 1975) containing 20\% (v/ v) egg yolk to a total concentration of approximately $250 \times 10^{6}$ spermatozoa $/ \mathrm{ml}$. The diluted semen was cooled to $4^{\circ} \mathrm{C}$ and an equal volume of Tris-fructose-citric acid extender, containing $20 \%$ (v/v) egg yolk and $12 \%$ (v/v) glycerol, was added. Thus the final sperm concentration was $120-140 \times 10^{6}$ spermatozoa $/ \mathrm{ml}$. After $2 \mathrm{~h}$ of equilibration at $4^{\circ} \mathrm{C}$, the diluted semen was filled into $0.5 \mathrm{ml}$ plastic straws (IMV, L'Aigle, France). The straws were frozen in an automatic programmable freezer (Planer Kryo 10, Planer Products Ltd, London, UK) with an average freezing rate of $-13 \cdot 2^{\circ} \mathrm{C} /$ min before being transferred to liquid nitrogen for storage. Thawing was performed by keeping the straws immersed in a $70^{\circ} \mathrm{C}$ water bath for $8 \mathrm{sec}$.

Detection of oestrus and insemination. Oestrus was detected and time of insemination determined by the farmer, based on vulval swelling and electrical resistance of the vagina (Møller, 1980). All vixens were inseminated twice at $24-\mathrm{h}$ intervals, as described by Fougner et al. (1973), with approximately $100-150 \times 10^{6}$ progressively motile spermatozoa.

Statistical methods. Data were examined by analysis of variance and Scheffe's test. Values are expressed as mean \pm s.e.m.

\section{Results}

\section{LH and testosterone}

The patterns of $\mathrm{LH}$ and testosterone release during the first $60 \mathrm{~min}$ after $\mathrm{GnRH}$ injection in June 1986 for 3 control animals (Group N) and 3 animals in Group 6L are shown in Fig. 2 (a \& b). LH concentrations rose within $20 \mathrm{~min}$ of injection in all 6 foxes, and there was no significant difference $(P>0.05)$ in response to GnRH. There was, however, a clear difference $(P<0.01)$ in the ability of the testes to release testosterone in response to the LH challenge. In June the total amount of testosterone released during the first $60 \mathrm{~min}$ after GnRH injection differed significantly between groups $(P<0.05)$ (Group N: $336 \pm 63 \mathrm{nmol} / 160 \mathrm{~min}^{-1}$; Group 6L: $877 \pm 151 \mathrm{nmol} / 1$ $60 \min ^{-1}$ ).
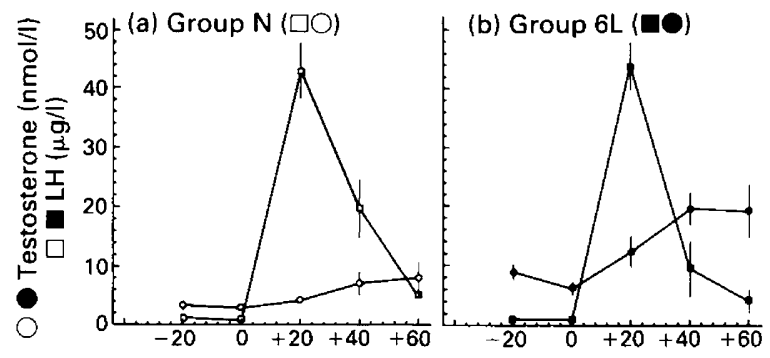

Min. before $\{-1$ and after $(+\mid \mathrm{GnRH}$ injection (0)

Fig. 2. Plasma concentrations of $\mathrm{LH}$ and testosterone (means \pm s.e.m.) in response to GnRH injections in June 1986 in (a) 3 males in Group N subjected to natural daylight and (b) 3 males in Group 6L subjected to short days (6L:18D) from February 1986. All samples were taken at 20-min intervals. The intramuscular GnRH injections were given immediately after the second blood sample.

The effect of GnRH on plasma concentrations of LH in October and November 1986 in males from Groups $N: 6 L: N(N=2)$ and $N: N: N(N=2)$ indicated no variation in $L H$ release, but total testosterone release during the first $60 \mathrm{~min}$ after $\mathrm{GnRH}$ injection was twice as high in animals in Group N:6L:N than in Group N:N:N in October and November (Fig. 3).

The total testosterone response after $\mathrm{GnRH}$ injection in February 1987 in Group 6L:6L:N animals $(N=2)$ also differed from that of animals in Group $N: N: N(N=2)$ or Group $6 L: N: N$ $(\mathrm{N}=2$ ) (Fig. 4). 


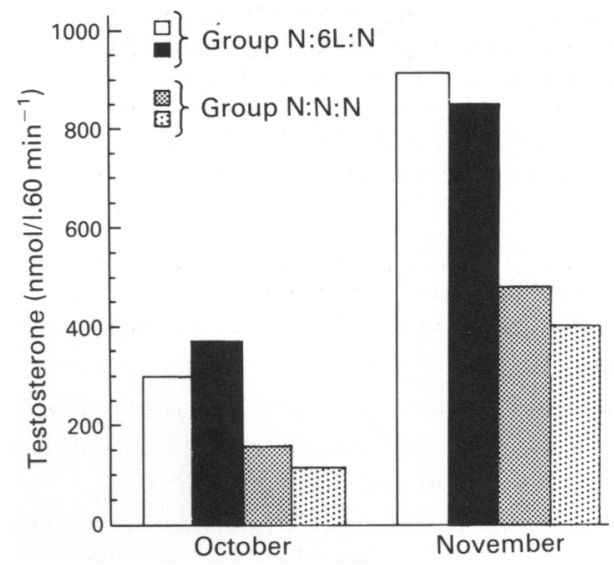

Fig. 3. Testosterone response after GnRH challenge in October and November 1986 in 2 males in Group N:N:N subjected to natural daylight since February 1986 and 2 males in Group N: 6L:N subjected to natural daylight from February until June 1986 and then moved to short days (6L:18D).

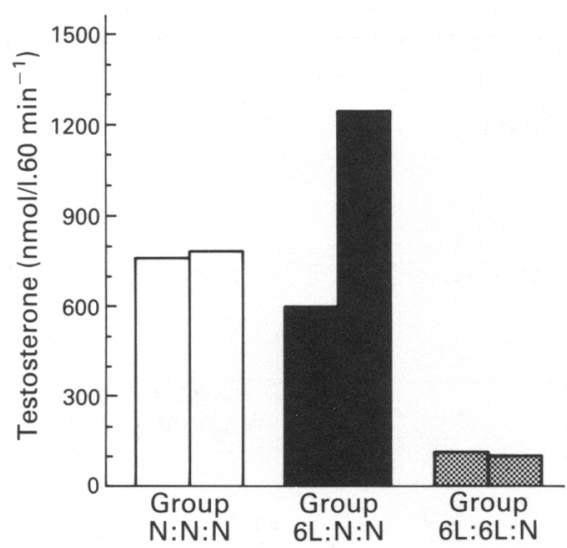

Fig. 4. Testosterone response after GnRH challenge in February 1987 in 2 males in Group N: $\mathrm{N}: \mathrm{N}$ housed under natural daylight conditions since February 1986, 2 males in Group 6L:N:N subjected to 6L:18D between February and June 1986 and then transferred to natural daylight, and 2 males in Group 6L:6L:N exposed to short days (6L:18D) from February until December 1986 and then moved to natural daylight.

The numbers of animals sampled in October and November 1986 and February 1987 were too low to allow a statistical analysis of the variations in $\mathrm{LH}$ and testosterone.

\section{Testicular histology}

In histological sections obtained from 2 males in Group 6L killed in June, most tubules contained elongated spermatids or more advanced cell types $(>70 \%)$ while the rest of the tubules contained cells up to the round spermatid stage, indicating full spermatogenic activity as in normal fully active testes. 
Semen collection and fertility trials

During the 2nd week of June 1986 attempts to collect semen from the males in Group $6 \mathrm{~L}$ and Group $\mathrm{N}$ were undertaken. All 6 males in Group 6L were co-operative during the collection procedure and 3 produced semen but only prostatic fluid was obtained from the others. No ejaculates were obtained from the 8 males in Group $\mathbf{N}$.

During the last week of November 1986 it was possible to collect normal semen from 1 male in Group 6L:6L:N and from all 5 males in Group N:6L:N. Semen collection failed in the other male in Group 6L:6L:N and all males in Groups 6L:N:N and N:N:N.

In the 1st week of February 1987, 1 year after the study began, it was possible to collect semen with motile spermatozoa present, at a normal density, from all males in Groups $6 \mathrm{~L}: \mathrm{N}: \mathrm{N}, \mathrm{N}: 6 \mathrm{~L}: \mathrm{N}$ and N:N:N. Semen collection failed in the 2 males in Group 6L:6L:N, which had started to shed their winter coat and showed clinical signs of testicular regression at the end of December 1986 and early January 1987 , i.e. 11 months after the study began.

Sperm characteristics of the semen collected and frozen on 3 consecutive days in June and December 1986 are shown in Table 1. There was no significant difference in the pre-freezing characteristics (volume, concentration and motility) between ejaculates in June and December $(P>0.05)$. The most striking result was the low $(P<0.01)$ post-thaw motility of the semen frozen in June.

Table 1. Sperm characteristics of ejaculates collected and frozen in June and December 1986 from 8 silver fox males subjected to different photoperiodic treatments beginning in February 1986 (for details of experimental design see Fig. 1)

\begin{tabular}{lccc}
\hline & Group & Group & Group \\
& $6 \mathrm{~L}$ & $6 \mathrm{~L}: 6 \mathrm{~L}: \mathrm{N}$ & N:6L:N \\
\hline Time of freezing & June & December & December \\
No. of males & 3 & 1 & 4 \\
No. of ejaculates & 9 & 3 & 11 \\
Volume $(\mathrm{ml})$ & $0 \cdot 27 \pm 0 \cdot 04^{\mathrm{a}}$ & $0 \cdot 38 \pm 0 \cdot 07^{\mathrm{a}}$ & $0 \cdot 40 \pm 0 \cdot 06^{\mathrm{a}}$ \\
Concentration $\left(\times 10^{6} \mathrm{ml}^{-1}\right)$ & $450 \pm 48^{\mathrm{a}}$ & $613 \pm 104^{\mathrm{a}}$ & $572 \pm 63^{\mathrm{a}}$ \\
Pre-freezing motility $(\%)$ & $77 \pm 4^{\mathrm{a}}$ & $85 \pm 3^{\mathrm{a}}$ & $86 \pm 2^{\mathrm{a}}$ \\
Post-thaw motility $(\%)$ & $22 \pm 4^{\mathrm{a}}$ & $55 \pm 13^{\mathrm{b}}$ & $54 \pm 3^{\mathrm{b}}$ \\
\hline
\end{tabular}

Values are the mean \pm s.e.m.

${ }^{a, b}$ Means in a row with different superscript letters are significantly different $(P<0.01)$.

To test the fertility of the semen frozen outside the normal breeding season, 10 blue fox vixens were inseminated the following breeding season. Ejaculates with a post-thaw motility less than $30 \%$ were discarded. Three vixens inseminated with semen collected in June from 3 males in Group $6 \mathrm{~L}$ failed to produce litters. One vixen inseminated with semen collected in December from 1 male in Group 6L:6L:N conceived and gave birth to 3 pups. All 6 vixens inseminated with semen collected in December from 4 males in Group N:6L: $N$ conceived with an average litter size of $8 \cdot 8 \pm 1 \cdot 7$.

\section{Discussion}

The results obtained for silver fox males maintained under natural photoperiodic conditions or subjected to different lengths of $6 \mathrm{~L}: 18 \mathrm{D}$ photoperiod indicate that short days are necessary if gonadal stimulation is to occur. Other investigations with this species support this finding (Lloyd \& Englund, 1973; Maurel \& Boissin, 1981). Similar results have also been reported for male mink (Mustela vison) (Boissin-Agasse et al., 1982) and blue foxes (Alopex lagopus) (Smith et al., 1984, $1985,1986,1987)$, which are also short-day breeders. Furthermore, our experiments show that short days not only stimulate redevelopment of the testes but can also inhibit testicular regression. 
Exposure to 6L:18D from February to June demonstrated the short-day inhibitory effect on testicular regression (Group 6L). However, only 3 of the 6 males kept in $6 \mathrm{~L}: 18 \mathrm{D}$ during the spring months produced semen. The poor quality and poor fertilizing ability of the frozen semen from these males cannot be fully explained and needs further investigation. It is possible that the semen was damaged by heat since the animals still had their winter coats in late May and early June, when the days often were very warm $\left(20-25^{\circ} \mathrm{C}\right)$. Lowered fertility has been found in boars during or shortly after the warm summer period, and heat stress experiments have produced the same result (Malmgren \& Larsson, 1984). The heat-stress hypothesis is supported by the fact that one of the light-treated males that produced non-fertilizing semen in June, produced fertilizing semen in December after being subjected to a $6 \mathrm{~L}: 18 \mathrm{D}$ lighting regimen during the autumn.

To obtain 100-150 $\times 10^{6}$ motile spermatozoa per insemination dose the inseminated volume was adjusted according to the post-thaw motility and the inseminated volume ranged between 1.5 and $2.5 \mathrm{ml}$. It appears from investigations in cattle that the importance of sperm numbers far outweighs any effect of semen volume on fertility (Olds et al., 1953). In the present investigation an egg-yolk-Tris extender was used for semen preservation. It has been shown that egg-yolk diluents can induce uterine antibody titers that may adversely affect fertility in cattle, but it is not known what effect dosage has on this response (Griffin et al., 1971).

Two males were kept in 6L:18D for 317 days (6 Feburary-20 December) and then transferred to natural daylight conditions (Group 6L:6L:N). At the location of the study in Sweden, the daylength in December and January varies between 6 and $8 \mathrm{~h}$, corresponding to a short-day lighting regimen. In both males, spontaneous testicular regression began about late December/ early January. Whether this is an expression of photorefractoriness, a physiological state of temporary unresponsiveness to a light cycle, is unclear. In many species, a period of sensitivity to a light cycle is followed by a period of insensitivity. The phenomenon of photorefractoriness has been studied in birds and mammals (Turek \& Campbell, 1979). Exposure of rams (a short-day breeder) to prolonged periods of stimulatory short days resulted in gonadal redevelopment, but after 16 weeks alternating periods of gonadal involution and reactivation were observed (Almeida \& Lincoln, 1984). This demonstrates that rams display reproductive photorefractoriness, since the changes in testis activity proceed independently of the photoperiod. In some photoperiodic animals, annual cycles in reproductive activity can be observed, implying that photoperiod not only induces and terminates reproductive events, but also synchronizes an endogenous annual rhythm so that reproductive events occur at the appropriate time of the year (Pengelley, 1974; Gwinner, 1981). In the 2 silver fox males maintained in a prolonged period of 6L:18D in the present study, testicular regression was observed after $\sim 1$ year of exposure. Consideration must therefore be given to the possibility that such a long-term cycle could represent an endogenously generated circannual rhythm in the absence of an annual synchronizaton by daylight.

Two males exposed to 134 consecutive short days (6 February-20 June) and then transferred to natural daylight displayed testicular regression after the transfer (Group 6L:N:N). Both animals maintained their capacity for testicular reactivation the following breeding season, and at semen collections during the breeding season no difference in sperm quantity or quality was observed between these males and control males, indicating that reactivation is a flexible response.

Exposure to a $6 \mathrm{~L}: 18 \mathrm{D}$ photoperiod from June to December also demonstrated the stimulatory effect that short days have on testicular redevelopment (Group N:6L:N). Under natural daylight conditions, testicular regression in the silver fox male takes place in spring as the days become longer. Results from this investigation indicate that the normal physiological role of long days or increasing daylight may be to terminate the breeding season and re-establish a mechanism whereby the animal will again be sensitive to decreasing daylength or short days. When this short-day sensitivity mechanism is restored, photostimulation by short days should hasten testicular redevelopment, analogous to the long-day sensitivity mechanism described in the stallion (Clay et al., 1987). Considering the relatively long time required to restore full reproductive capacity, it is not surprising that males should rely on a reproductive system that can 'forese' the approaching 
breeding season rather than relying on cues generated by critical daylengths during the breeding season (Elliot \& Goldman, 1981).

The light-induced changes in testicular function reported here are most probably mediated through alterations in melatonin secretion (Turek \& Campbell, 1979). We are presently trying to determine whether the light-induced effects on the reproductive system can be mimicked by exposing silver fox males to high concentrations of exogenous melatonin released by subcutaneous implants.

Silver fox males kept for fur production are semi-wild animals, making blood sampling difficult. In our experiments blood had to be collected at frequent intervals and this could not be done with unanaesthetized animals. There are reports indicating that acepromazine and ketamine may interfere with LH release in sheep, possibly due to inhibition of GnRH secretion (Peet \& Lincoln, 1977; Clarke \& Doughton, 1983). However, in our study, experimental and control animals were challenged by a high $\mathrm{GnRH}$ dose and were treated the same way as regards anaesthesia. It is reasonable to assume that any interference with neuroendocrine function caused by the anaesthetics was hidden or abolished by the administration of $\mathrm{GnRH}$, as seen by the massive $\mathrm{LH}$ discharge induced. In later experiments acepromazine $(2 \mathrm{mg} / \mathrm{kg})$ has been used as the sole sedative. No difference in $\mathrm{LH}$ release in response to $\mathrm{GnRH}$ administration has been observed between these animals and the animals in this study treated with acepromazine and ketamine.

In conclusion, we believe that artificial illumination can be used to increase the reproductive capacity of silver fox males. To induce a reproductive season in late autumn/early winter, the silver fox male should be exposed to a period of long days before exposure to short days. We believe that long days are necessary to initiate the new breeding season by re-establishing the sensitivity of the reproductive system to short days, and that once the sensitivity has been restored short days act to expedite the ongoing process. To inhibit regression in reproductive activity and extend the normal reproductive season in the spring the males should be exposed to short days because the decreased daylength acts to maintain sperm production. The length of photoperiodic stimulation necessary for maintaining optimal levels of sperm output and semen fertility has yet to be determined.

We thank Dr Gordon Niswender for supplying the LH antibody; Dr Leo Reichert for supplying the dog LH; Dr Kjell Andersen-Berg for intepreting histological sections; and the Norwegian and Swedish Fur Breeders Associations for financial support.

\section{References}

Aamdal, J. (1972) Investigation in the reproduction in the blue fox. In Riproduzione Animale e Fecondazione artificale, pp. 1-6. Edizione Agricole, Bologna.

Almeida, O.F.X. \& Lincoln, G.A. (1984) Reproductive photorefractoriness in rams accompanying changes in the patterns of melatonin and prolactin secretion. Biol. Reprod. 30, 143-158.

Andersen, K. (1975) Insemination with frozen dog semen based on a new insemination technique. Zuchthygiene 10, 1-4.

Boissin-Agasse, L., Boissin, J. \& Ortavant, R. (1982) Circadian photosensitive phase and photoperiodic control of testis activity in the mink (Mustela vison peale and beavois), a short-day mammal. Biol. Reprod. 26, 110-119.

Clarke, I.J. \& Doughton, B.W. (1983) Effect of various anaesthetics on resting plasma concentrations of luteinizing hormone, follicle-stimulating hormone and prolactin in ovariectomized ewes. J. Endocr. 98, 79-89.
Clay, C.M., Squires, E.L., Amann, R.P. \& Pickett, B.W. (1987) Influences of season and artificial photoperiod on stallions: testicular size, seminal characteristics and sexual behavior. J. Anim. Sci. 64, 517-525.

Elliot, J.A. \& Goldman, B.D. (1981) Seasonal reproduction, photoperiodism and biological clocks. In Neuroendocrinology of Reproduction: Physiology and Behavior, pp. 377-423. Ed. N. T. Adler. Plenum Press, New York.

Fougner, J.A., Aamdal, J. \& Andersen, K. (1973) Intrauterine insemination with frozen semen in the blue fox. Nord. VetMed. 25, 144-149.

Greenwood, F.G., Hunter, W.H. \& Glover, J.S. (1963) The preparation of ${ }^{131} \mathrm{I}$-labelled human growth hormone of high specific radioactivity. Biochem. $J$. 89, 114-123.

Griffin, J.F.T., Nunn, W.R. \& Hartigan, P.J. (1971) An immune response to egg-yolk semen diluent in dairy cows. J. Reprod. Fert. 25, 193-199. 
Gwinner, E. (1981) Circannual clocks: their dependence on the circadian system. In Biological Clocks in Seasonal Reproductive Cycles, pp. 153-169. Eds B. K. Follett \& D. E. Follett. Wright, Bristol.

Haeger, O. \& Mäckle, N. (1971) Ein Zweiphasenverdünner in der Praxis der Schweinebesamung. Dtsch. Tierärztl. Wschr. 78, 395-397.

Kuznetsov, G.A. (1979) Producing two litters per year from arctic foxes. Nauch. Trudȳ nauchnoissled. Inst., Pushnogo Zverovod. Krolikovod. 20, 5-10.

Lloyd, H.G. \& Englund, J. (1973) The reproductive cycle of the red fox in Europe. J. Reprod. Fert., Suppl. 19, 119-130.

Malmgren, L. \& Larsson, K. (1984) Semen quality and fertility after heat stress in boars. Acta vet. scand. 25, 425-435.

Maurel, D. \& Boissin, J. (1981) Plasma thyroxine and testosterone levels in the red fox (Vulpes vulpes L.) during the annual cycle. Gen. comp. Endocrinol. 43, 402-404.

Mondain-Monval, M., Bonnin, M., Canivenc, R. \& Scholler, R. (1984) Heterologous radioimmunoassay of fox LH: Levels during the reproductive season and the anoestrus of the red fox (Vulpes vulpes L.). Gen. comp. Endocrinol. 55, 125-132.

Møller, O. (1980) Elektrisk brunstdiagnostikk hos blårev, sölvrev og mårhund-et nytt hjelpemiddel $\mathrm{i}$ paringssesongen. Norsk Pelsdyrblad 54, 591-595.

Olds, D., Seath, D.M., Carpenter, M.C. \& Lucas, H.L. (1953) Interrelationships between site of deposition, dosage and number of spermatozoa in diluted semen and fertility of dairy cows inseminated artificially. $J$. Dairy Sci. 36, 1031-1035.

Oltner, R., Lundström, K. \& Edqvist, L-E. (1979) LH and testosterone in monozygous growing bulls. Swedish J. agric. Res. 9, 151-161.
Peet, M.J. \& Lincoln, G.A. (1977) Blockade of episodic gonadotrophin secretion by Immobilon in ovariectomized ewes. J. Reprod. Fert. 50, 97-100.

Pengelley, E.T. (1974) Circannual Clocks. Academic Press, New York.

Smith, A.J., Clausen, O.P.F., Kirkhus, B., Jahnsen, T., Moller, O.M. \& Hansson, V. (1984) Seasonal changes in spermatogenesis in the blue fox (Alopex lagopus) quantified by DNA flow cytometry and measurement of soluble $\mathrm{Mn}^{2+}$-dependent adenylate cyclase activity. J. Reprod. Fert. 72, 453-461.

Smith, A.J., Mondain-Monval, M., Moller, O.M., Scholler, R. \& Hansson, V. (1985) Seasonal variations of $\mathrm{LH}$, prolactin, androstenedione, testosterone and testicular FSH binding in the blue fox (Alopex lagopus). J. Reprod. Fert. 74, 449-458.

Smith, A.J., Bugge, H.P., Andersen Berg, K., Moller, O.M. \& Hansson, V. (1986) Seasonal changes in testicular structure and function in the blue fox (Alopex lagopus), quantified by morphometrical analysis and adenylate cyclase activity. Int. J. Androl. 9, 53-66.

Smith, A.J., Mondain-Monval, M., Andersen Berg, K., Simon, P., Forsberg, M., Clausen, O.P.F., Hansen, T., Moller, O.M. \& Scholler, R. (1987) Effects of melatonin implantation on spermatogenesis, the moulting cycle and plasma concentrations of melatonin, $\mathrm{LH}$, prolactin and testosterone in the male blue fox (Alopex lagopus). J. Reprod. Fert. 79, 379-390.

Stupnicki, R. \& Madej, A. (1976) Radioimmunoassay of LH in blood plasma of farm animals. Endokrinologie 68, 6-13.

Turek, F.W. \& Campbell, C.S. (1979) Photoperiodic regulation of neuroendocrine-gonadal activity. Biol. Reprod. 20, 32-50.

Received 28 November 1988 